\title{
ENTOMOLOGY
}

\section{Is the alien species Clepsis peritana (Lepidoptera: Tortricidae) settling in Italy?}

\author{
M. Pinzari, ${ }^{1}$ Z. Zerunian, ${ }^{2}$ M. Pinzari ${ }^{3}$ \\ ${ }^{1}$ Dipartimento di Biologia, Università di Roma Tor Vergata; ${ }^{2}$ Assisi (PG); ${ }^{3}$ Dipartimento di Ingegneria, Università di \\ Roma 3, Italy
}

\begin{abstract}
Clepsis peritana (Clemens, 1860) is a native species of North America that has been accidentally introduced in Europe in 80's. This species was mentioned as occurring in Gibraltar, Spain, Denmark and Italy, but no precise collecting data were provided. The presence of the garden tortrix, Clepsis peritana, in Italy is confirmed by a single specimen collected in Central Italy (Umbria region) that is identified by both external characters and dissection of the male genitalia.
\end{abstract}

\section{Introduction}

The Region of Umbria (Central Italy) has its economy mainly based on agriculture; for this reason, a particular attention has been given to the alien species and in particular to those that could be dangerous to agricultural crops.

Correspondence: Manuela Pinzari, Dipartimento di Biologia, Università di Roma Tor Vergata, Via della Ricerca Scientifica, 1 - 00133 Roma, Italy.

Tel.: +39.06.72595950 -Fax: +39.06.7259.

E-mail: manuela.pinzari@uniroma2.it.

Key words: Clepsis peritana, garden tortrix, moth, alien species.

Contributions: the authors contributed equally.

Conflict of interest: the authors declare no potential conflict of interest.

Funding: none.

Received for publication: 9 May 2018.

Revision received: 6 June 2018.

Accepted for publication: 6 June 2018

(C) Copyright M. Pinzari et al., 2018

Licensee PAGEPress, Italy

Journal of Entomological and Acarological Research 2018; 50:7551

doi:10.4081/jear.2018.7551

This article is distributed under the terms of the Creative Commons Attribution Noncommercial License (by-nc 4.0) which permits any noncommercial use, distribution, and reproduction in any medium, provided the original author(s) and source are credited.
The study of the Lepidopterofauna in the surroundings of Assisi has already shown the presence of various alien or harmful species such as Coleophora texanella (Chambers, 1878), Zelleria oleastrella (Millière, 1864), Prays oleae (Bernard, 1788), Cydalima perspectalis (Walker, 1859), Sitotroga cerealella (Olivier, 1789), Tuta absoluta (Meyrick, 1917) and others (Zerunian \& Zilli, 2014; Pinzari et al., 2016). This study is still ongoing but already more than 40 species of moths that are new for the local fauna have been collected.

Among these species, here, we report a new record of Clepsis peritana (Clemens, 1860), an alien species native of North America.

\section{Materials and Methods}

\section{The species examined}

Clepsis peritana is a species belonging to the family of Tortricidae and native of North America; here, it is present from Nova Scotia to British Columbia in Canada to Southern California and Cuba. It is known as "garden tortrix" or "strawberry garden tortrix" due to its food plants and habits. The species is invasive in gardens and strawberry crops. The food plants are mainly strawberry, lima bean, fuchsia (Razowski, 2002) and probably other plants as the larvae were found feeding on fallen fruit of orange and leaves of various ornamental plants (Powell, 1964; Razowski, 1979). It occurs in a number of generations yearly (from 2-4 to in the North to 6 or 7 generations in the South). The adults fly from March to September and overwinter as larva or chrysalis. In southern California adults are present during most of the year; in central California adults are present from April through June and again in August through October.

The preimaginal stages although known were never described. Eggs are deposited in small masses of approximately 10-20 individual eggs. Larvae live in silk tubes built on the surface of leaves and feed on dead or decaying leaf litter. Larvae will occasionally feed in the buds or fruits of living plants. On strawberry larvae may cause damage to fruit in contact with the ground by webbing leaves to the fruit and chewing holes in the berries. In citrus groves larvae feed on decaying leaves until population levels are high, at which point they switch to feeding on citrus fruit. Significant damage to citrus is caused only when fruit is close to the ground or has dropped from the tree.

In Europe, the species was recorded for the first time in three localities in Denmark (Larsen and Vilhelmsen, 1991): two specimens on 4 September, 1987, and 9 August, 1988 in Vanlose (F. Vilhelmsen leg.); 1 ex on 2 July, 1989 in Kysingnaes (E. 
Vesterhede leg.); finally, on November 1989 in Roskilde inside a greenhouse where many larvae were observed on Euphorbia pulcherrima Willd., 1834 (H.P. Ravn, leg.) (Buhl et al., 1991). Razowski (2002) said that Clepsis peritana has been accidentally introduced and has settled in Denmark but in this country it results still absent on the basis of Fauna Europaea (Aarvik, 2013). The species was observed in 2000 in Spain in Fuengirola (Granada) (Nupponen et al., 2003) and in 2006 in Gibraltar (Clifton, 2007). Here, on 9 May, 2006, C. Perez collected two males of Clepsis peritana and also the conspecific C. coriacana (Rebel, 1894), new for Europe (Clifton, 2007). In these countries, adults are present from March to September with several generations per year. Larvae therefore feed on leaves of Chrysanthemum sp., Cynara cardunculus L., Senecio jacobaea L., Stachys sp., Fragaria sp., Citrus sp., Scrophularia californica Cham. \& Schldl. and Solanum torvum Swartz (Ciampitti et al., 2016).

In Italy, Clepsis peritana was collected by an early detection of the alien species planned by Regione Lombardia during EXPO2015, the universal exposition hosted by Milan (Ciampitti et al., 2016). Expo participants included more than 140 countries and they were hosted in individual or grouped pavilions exhibiting a large variety of plants, seeds and fruits from every part of world. The species was captured on $3^{\text {th }}$ September, 2015 in the pavilion "Ungheria" by using a Pagoda Delta Trap with glue and, as attractant, the pheromone Pherodis-Koppert (Berkel en Rodenrijs, The Netherlands). This pheromone is used for monitoring of Tecia solanivora (Povolný, 1973) (Gelechiidae). The trap was located near plants of potato (Solanum tuberosum L.) in the pavilion "Ungheria" (Ciampitti et al., 2016).

\section{Species identification}

Clepsis peritana has a relatively characteristic habitus but the background colour of upper surface of wings can be more or less dark up to single-color specimens (Razowski, 2002). In Europe, the species could be confused with three species: Clepsis consimilana (Hübner, 1817), Argyrotaenia ljungiana (Thunberg, 1797) and Clepsis coriacana (Rebel, 1894). This misidentification could occur if the species is identified only on the habitus of old or damaged specimens. However, the examination of genitalia allows to discriminate with certainty $C$. peritana among those species. In the male genitalia, this species can be easily recognized by the features and the shape of uncus (Razowski, 2002).

Our specimen (male) has a fresh wing pattern and the distinctive external habitus of C. peritana (Figure 1A). Hence, the dissection of the male genitalia (gen. prep. PREPT 1610, M. Pinzari) confirmed the determination made by using only the external habitus. Genital parts were mounted on a microscope slide (Figure 1B) and preserved in the private collection of Mario Pinzari (Rome, Italy).

\section{Results}

RECORDS. $1 \hat{\delta}$ (gen. praep. PREPT 1610, M. Pinzari), Italia, Umbria, Assisi (PG), m 200, Frazione Palazzo, 26.X.2017, Z. Zerunian leg.

Notes. A single male of $C$. peritana was collected by Zerun Zerunian during night on 26 October 2017 at Frazione Palazzo near Assisi (Perugia), Umbria, in Central Italy. The specimen was attracted to a $100 \mathrm{~W}$ - incandescent bulb. The specimen is deposited in the private collection of Mario Pinzari (Rome, Italy).

\section{Discussion and Conclusions}

The first Italian record of Clepsis peritana was associated to a case of accidental import due to the event of EXPO2015 exhibition. The species was probably introduced in Milan from Ungheria since it was collected by a single pheromone trap in the pavilion of this country. For this country, $C$. peritana however is not reported. A dedicated detection on this species would be needed in the area of origin of potato plants (Solanum tuberosum L.). These plants therefore are not known as host plants of $C$. peritana. However, we can exclude that neither $C$. peritana collected during the EXPO2015 exhibition come from other countries nor it feed on other host plants since the species clearly appears to be polyphagous (Ciampitti et al., 2016).

After the observation in Milan, C. peritana has never been reported again in Italy. The low number of the observations on $C$.
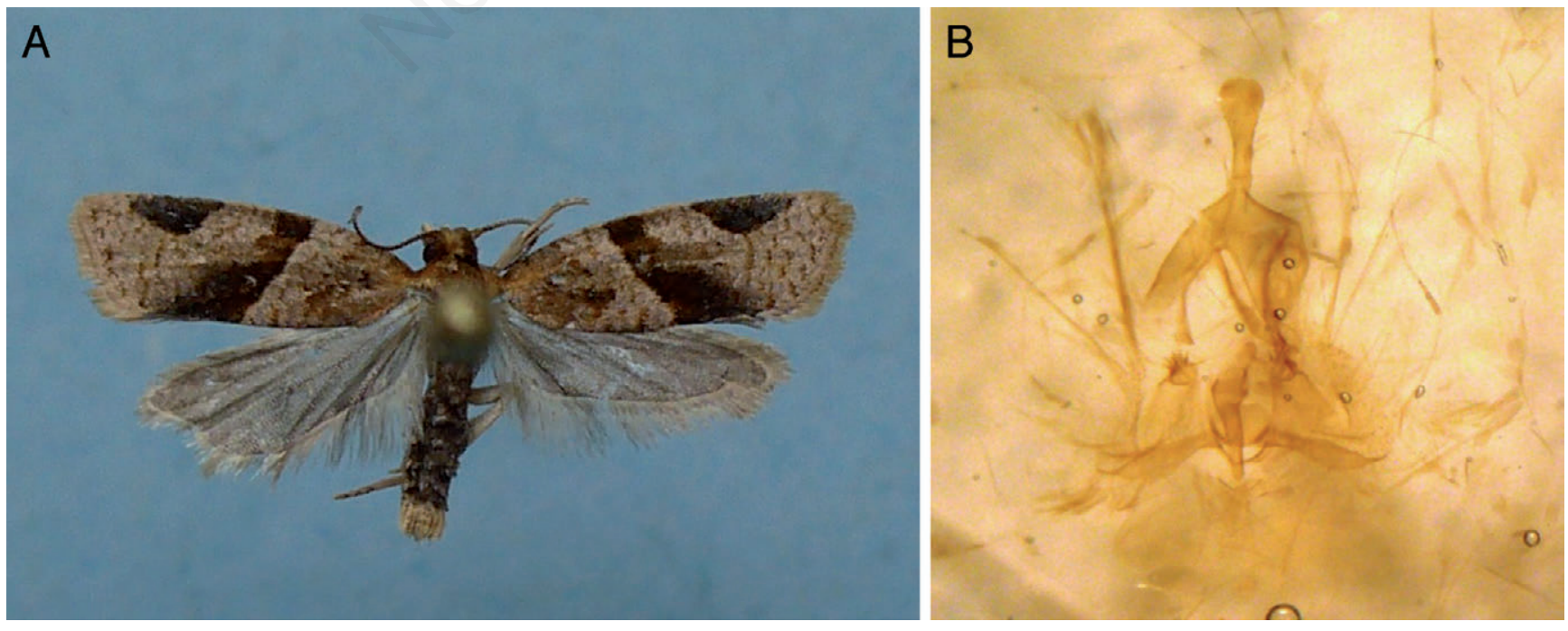

Figure 1. Male of Clepsis peritana (Clemens, 1860): adult (A) and genitalia (B) (PREPT 1610, Mario Pinzari). 
peritana in Europe and the disappearance of the colony in Denmark (Buhl, et al., 1991; Razowski, 2002) let us think that the species has difficulty to settle permanently in Europe.

Our single observation on occurrence of $C$. peritana in Umbria does not allow affirming that the species has been established in Italy, however, it is another important contribution in shaping the garden tortrix species distribution that could be in expansion in Palearctic region.

Finally, it would be fascinating to study museum and private entomological collections for providing additional data and a best picture on the occurrence of Clepsis peritana in Europe.

To identify new hotbeds for alien species before its establishment it is essential to take promptly preventive measure against other accidental introductions and make effective and inexpensive management practice.

\section{References}

AARVIK L.E., 2013 - Fauna Europaea: Tortricidae. In: Karsholt O. \& Van Nieukerken E.J. Fauna Europaea: Lepidoptera, Moths. Fauna Europaea version 2017.06. Available from: https://fauna-eu.org

BUHL O., FALCK P., JORGENSEN B., KARSHOLT O., LARSEN K. SCHNACK K. 1991 - Records of Microlepidoptera from Denmark in 1989 (Lepidoptera). Entomologiske Meddelelser 59: 29-40.

CIAMPITTI M., SIENA F., PATTI C., ZANOTTI M., 2016 -
Relazione finale del piano di monitoraggio fitosanitario del Sito espositivo EXPO 2015. ERSAF, 139 pp.

CLIFTON J. 2007 - Clepsis coriacana (Rebel, 1894) new to Europe plus further records of Clepsis peritana (Clemens, 1860) from Gibraltar (Lepidoptera: Tortricidae). - Shilap Revta. Lepid. 35: 47-48.

FREEMAN T.N. 1958 - The Archipinae of North America (Lepidoptera: Tortricidae). The Canadian Entomologist. 90: 89.

LARSEN K., VILHELMSEN F. 1991 - Clepsis peritana (Clemens, 1860) fundet I Danmark (Lepidoptera, Tortricidaae). - Lepidoptera, 4: 22-24.

NUPPONEN K., NUPPONEN T., SAARELA E., SIPPOLA L. 2003 - New records on Microlepidoptera from the western Mediterranean region (Lepidoptera: Nepticulidae, Scythridae, Tortricidae). - Shilap Revta. Lepid. 31: 229-33.

PINZARI M., ZERUNIAN Z., PINZARI M. 2016 Microlepidotteri di Assisi (Italia) (Lepidoptera). - Boll. Assoc. Rom. Entomol. 71: 107-200.

POWELL J.A. 1964 - Biological and taxonomic studies on tortricine moths, with reference to the species in California. - University of California Publications in Entomology. Vol. 32: 317 pp.

RAZOWSKI J., 1979 - Revision of the genus Clepsis Guenée (Lepidoptera: Tortricidae). Part II - Acta Zool. Cracov. 24: 113-52.

RAZOWSKI J. 2002 - Tortricidae of Europe, 1. Tortricinae and Chlidanotinae. - Slamka, Bratislava: $247 \mathrm{pp}$.

ZERUNIAN Z., ZILLI A., 2014 - The Macrolepidoptera of Mt Subasio (Umbria, Central Italy). In Zilli A. (Ed.), Lepidoptera research in areas with high biodiversity potential in Italy, Volume 1. Natura Edizioni Scientifiche, Bologna: 9-104. 